\title{
TINGKAT PENDIDIKAN IBU MEMILIKI HUBUNGAN DENGAN STATUS PERKEMBANGAN MOTORIK HALUS ANAK USIA PRASEKOLAH
}

\author{
Agus Warseno, Hidayatus Solihah \\ Prodi Keperawatan, Universitas Jenderal Achmad Yani Yogyakarta \\ E-mail: gusmotivation@gmail.com
}

\begin{abstract}
ABSTRAK
Latar Belakang Perkembangan pada anak usia prasekolah dapat dilihat dari perkembangan motorik halus. Salah satu faktor yang dapat memengaruhi perkembangan pada anak adalah faktor pendidikan orang tua terutama ibu.

Tujuan penelitian untuk mengetahui hubungan antara pendidikan ibu dengan perkembangan motorik halus anak usia prasekolah.

Metode penelitian ini kuantitatif non eksperimental, dengan pendekatan cross sectional. Penelitian dilakukan di TK Margomulyo Sleman Yogyakarta dan penentuan responden menggunakan teknik sampel total sebanyak 41 orang. Pengumpulan data menggunakan kuesioner dan DDST II. Analisa data menggunakan uji korelasi Spearman's dengan tingkat kemaknaan $\mathrm{p}<0,05$.

Hasil penelitian menunjukkan sebagian besar pendidikan terakhir yang di tempuh ibu adalah sekolah menengah atas yaitu 23 orang $(56,1 \%)$. Sebagian besar anak usia prasekolah di TK Margomulyo Sleman menunjukkan perkembangan motorik halus normal yaitu 33 orang $(80,5 \%)$ dan anak yang menunjukkan perkembangan motorik halus suspect sebanyak 8 orang $(19,5 \%)$. Hasil dari uji korelasi Spearman's didapatkan p-value 0,023 ( $\alpha=0,05)$.
\end{abstract}

Kesimpulan korelasi sebesar 0,354. Ada hubungan antara pendidikan ibu dengan perkembangan motorik halus anak usia prasekolah.

Kata Kunci : Anak prasekolah, Perkembangan motorik halus, Pendidikan ibu

\section{ABSTRACT}

Background Development in preschool children can be seen from fine motor development. One of the factors that can influence development in children is the education factor of parents, especially mothers.

Aim The purpose of this study was to determine the relationship between maternal education and fine motor development in preschool children.

Method This research method is quantitative non-experimental, with a cross sectional approach. The study was conducted at Margomulyo Sleman Sleman Kindergarten and the determination of respondents using a total sampling technique of 41 people. Data collection using questionnaires and DDST II. Data analysis uses the Spearman correlation test with a significance level of $p<0.05$.

Result The results of the study showed that most of the last education taken by mothers was high school, which was 23 people (56.1\%). Most preschoolers in Margomulyo Sleman Kindergarten showed normal fine motor development, namely 33 people (80.5\%) and children who showed suspect fine motor development as many as 8 people (19.5\%). The results of the Spearman correlation test obtained p-value $0.023(\alpha=0.05)$.

Conclution Correlation coefficient of 0.354. There is a relationship between maternal education and fine motor development in preschool children.

Keywords: Preschool, fine motor development, maternal education. 


\section{PENDAHULUAN}

Perkembangan pada anak meliputi perkembangan motorik kasar, perkembangan bahasa, perkembangan motorik halus dan perkembangan personal social (Santrock, 2011). Perkembangan motorik merupakan salah satu tugas perkembangan anak yang paling penting dalam masa prasekolah (usia 3-6 tahun) karena pada masa ini anak sangat aktif yang ditandai dengan bertambahnya aktivitas fisik, keterampilan dan peningkatan dalam proses berfikir. Perkembangan motorik halus adalah gerakan halus yang menggunakan otot-otot kecil tetapi memerlukan koordinasi mata yang cermat, sedangkan perkembangan motorik kasar yaitu gerakan yang melibatkan otot-otot besar (Soetjiningsih, 2013).

Perkembangan motorik halus adalah gerakan halus yang melibatkan otot-otot kecil yang dipengaruhi oleh fungsi motorik, fungsi visual dan kemampuan intelek nonverbal. Gerakangerakan dalam perkembangan motorik halus pada anak berbeda-beda tergantung dari usia anak (Soetjiningsih, 2013). Kegiatan yang dilakukan pada anak usia 3 - 6 tahun dengan melibatkan otot-otot halus dapat berupa menggambar tanda silang, menggambar lingkaran, menggambar orang dengan 3 bagian tubuh (kepala, badan, lengan), mengikat sepatu, meniru gambar bujur sangkar dan menjiplak segilima Cahyaningsih, 2011).

Perkembangan motorik yang terlambat dapat disebabkan oleh beberapa hal, salah satu penyebabnya adalah gangguan genetik atau kromosom seperti syndrome down, gangguan atau infeksi susunan saraf seperti palsi serebral, spina bifida, syndrome rubella (IDI, 2013). World Health Organization (2011) melaporkan angka kejadian keterlambatan perkembangan secara umum terjadi sekitar $10 \%$ pada anak-anak di seluruh dunia. Terdapat data masih tingginya angka kejadian gangguan pertumbuhan dan perkembangan anak usia balita khususnya gangguan perkembangan motorik sebesar 27,5\% (UNICEF, 2010). Di Indonesia sekitar 16\% anak dibawah usia lima tahun mengalami gangguan perkembangan saraf dan otak mulai dari ringan sampai berat. Prevalensi gangguan perkembangan anak meliputi keterlambatan motorik, berbahasa, perilaku, autisme dan hiperaktif bervariasi mulai dari 12,8\% sampai dengan $16 \%$, sedangkan standar indikator deteksi tumbuh kembang balita sebesar 90\% (Kementerian Kesehatan Republik Indonesia, 2012).

Faktor-faktor yang dapat memengaruhi penyimpangan perkembangan antara lain faktor genetik dan faktor lingkungan. Faktor genetik ini merupakan modal awal dalam mencapai suatu proses akhir dari tumbuh kembang anak. Faktor lingkungan dibagi lagi menjadi faktor biologis, 
faktor fisik, faktor psikososial dan faktor keluarga (pekerjaan keluarga, pendidikan orang tua, jumlah saudara, dan pola pengasuhan (Cahyaningsih, 2011).

Faktor keluarga dapat menghambat perkembangan anak terutama pada anak usia prasekolah, salah satu faktor dalam keluarga yang berpengaruh adalah pendidikan. Pendidikan orang tua terutama pendidikan ibu sangat mempengaruhi tumbuh kembang anak. Pendidikan ibu yang rendah membuat ibu kurang mampu dalam menyerap informasi tentang cara mengasuh anak yang baik dan tahapan-tahapan perkembangan apa saja yang dilewati anak sesuai usianya (Soetjiningsih, 2013).

\section{METODE PENELITIAN}

Penelitian ini merupakan kuantitatif yang menggunakan metode penelitian analitik korelasional dengan pendekatan cross sectional. Penelitian ini dilakukan di TK Margomulyo Sleman Yogyakarta pada bulan Maret sampai Agustus 2018. Populasi penelitian ini adalah anak usia prasekolah di TK Margomulyo sebanyak 41 anak. Teknik pengambilan sampel menggunakan total sampling.

Variabel bebas dalam penelitian ini adalah pendidikan ibu. Sedangkan variebel terikatnya perkembangan motorik halus anak usia prasekolah.

Pengumpulan data pendidikan ibu menggunakan kuesioner demografi. Alat yang digunakan untuk mengumpulkan data perkembangan motorik halus anak adalah dengan Denver Development Screening Test (DDST) II. Data yang sudah terkumpul kemudian dilakukan editing, coding, dan tabulating. Analisis data yang digunakan yaitu analisis univariat dan bivariat. Uji statistik menggunakan uji korelasi Spearman's.

\section{HASIL PENELITIAN}

\section{Karakteristik Responden}

Tabel 1 memperlihatkan sebagian besar umur ibu masuk dalam rentang usia 26-36 tahun sebanyak 75,6\%. Status pekerjaan yang dimiliki ibu sebagian besar adalah ibu rumah tangga sebanyak $80,5 \%$.

Tabel 2 memperlihatkan bahwa sebagian besar anak berusia 6 tahun sebesar $61 \%$. Sebagian besar jenis kelamin anak usia prasekolah di TK Margomulyo adalah laki-laki sebesar $65,9 \%$. Jumlah saudara yang dimiliki sebagian besar adalah tiga bersaudara sebesar 51,2\%. Perkembangan motorik halus yang dimiliki sebagian besar adalah normal sebesar $80,5 \%$. 


\section{Analisis Bivariat}

Hasil perhitungan statistik menggunakan uji korelasi Spearman's didapatkan nilai $p$ value sebesar $0,023<\alpha 0,05$ sehingga dapat disimpulkan bahwa Ha diterima Ho ditolak yang berarti ada hubungan antara pendidikan ibu dengan perkembangan motorik halus anak usia prasekolah di TK Margomulyo Sleman Yogyakarta. Nilai koefisien korelasi sebesar 0,354 menunjukkan keeratan hubungan antara pendidikan ibu dengan perkembangan motorik halus anak usia prasekolah di TK Margomulyo Sleman adalah rendah karena terletak pada rentang $0,20-0,399$.

\section{PEMBAHASAN}

\section{Karakteristik Ibu}

Umur ibu sebagian besar berada pada rentang umur 26 - 36 tahun sebanyak 31 orang $(75,6 \%)$. Seseorang yang berumur produktif (muda) lebih mudah menerima pengetahuan dibandingkan seseorang yang berumur tidak produktif (lebih dewasa) karena orang dewasa telah memiliki pengalaman yang mempengaruhi pola pikir sehingga sulit diubah. Semakin cukup umur, maka tingkat kematangan dan kekuatan seseorang akan lebih matang dalam berpikir dan bekerja (Notoatmodjo, 2010). Tugas perkembangan individu pada dewasa awal berupa dapat mulai bekerja, memilih pasangan, mulai membina keluarga, mengasuh anak, mengelola rumah tangga, mengambil tanggung jawab sebagai warga negara, dan mencari kelompok sosial yang menyenangkan. Seseorang dalam rentang usia 18 - 40 tahun lebih berperan aktif dalam masyarakat dan kehidupan sosialnya yang mempengaruhi penerimaan informasi sehingga dapat meningkatkan pengetahuan (Potter and Perry, 2012).

Pekerjaan ibu sebagian besar adalah ibu rumah tangga. Salah satu faktor pembentuk pengetahuan seseorang adalah lingkungan sosial termasuk didalamnya lingkungan kerja. Akan tetapi, seiring dengan perkembangan teknologi informasi dan komunikasi khususnya yang berbasis internet, memudahkan seseorang untuk memperoleh informasi dan sumber pengetahuan kapanpun dan dimanapun tanpa harus dibatasi oleh ruang dan waktu (Soekanto, 2010).

Pendidikan Ibu sebagian besar adalah sekolah menengah atas sebanyak 23 orang $(56,1 \%)$. Pendidikan turut menentukan mudah tidaknya seseorang menyerap dan memahami pengetahuan yang mereka peroleh. Pendidikan terakhir yang mampu ditempuh hanya sampai sekolah menengah atas atau sederajat dapat disebabkan karena rumah yang berada di desa jauh dari kota ditambah lagi dengan keadaan ekonomi yang tidak mencukupi sehingga akan kesulitan untuk melanjutkan sekolah sampai kejenjang yang lebih tinggi. Pada umumnya 
semakin tinggi pendidikan seseorang maka semakin baik pula pengetahuannya. Tingginya tingkat pendidikan seseorang dapat digunakan sebagai modal untuk menerima informasi sehingga dapat mempengaruhi pengetahuan seseorang (Notoatmodjo, 2010).

Pendidikan adalah arahan dan bimbingan kepada seseorang yang merupakan pengaruh dari pengalaman belajar yang terus-menerus dialami seseorang untuk mencapai suatu tingkat kedewasaan (Syah, 2010). Pendidikan memberikan nilai-nilai tertentu bagi manusia, terutama dalam membuka pikiran serta menerima hal-hal baru dan juga bagaimana berpikir secara ilmiah, dengan demikian orang yang berpendidikan tinggi akan lebih mudah dalam menerima dan mencerna ide-ide atau gagasan baru. Meningkatnya pendidikan berdampak pada pengalaman dan wawasan yang semakin luas dan kemampuan untuk mengambil keputusan yang baik khususnya yang berhubungan dengan kesehatan. Seseorang dengan tingkat pendidikan SMA atau sederajat sudah mampu dalam mengolah informasi yang didapat dan mempertimbangkan hal apa yang baik untuk dirinya termasuk dalam memelihara kesehatannya (Widyastuti dkk, 2010)

\section{Karakteristik Anak}

Sebagian besar umur anak di TK Margomulyo Sleman Yogyakarta yaitu 6 tahun sebanyak 25 anak (61\%). Anak usia prasekolah adalah anak yang berusia 3-6 tahun yang belum menempuh sekolah dasar (Wong dkk, 2009). Anak prasekolah adalah pribadi yang mempunyai berbagai macam potensi. Potensi-potensi itu dirangsang dan dikembangkan agar pribadi anak tersebut berkembang secara optimal (Supartini, 2010). Masa prasekolah adalah masa-masa untuk bermain dan mulai memasuki taman kanak-kanak. Waktu bermain merupakan sarana untuk tumbuh dalam lingkungan dan kesiapannya dalam belajar. ${ }^{21}$ Pada tahap perkembangan anak usia prasekolah ini, anak mulai menguasai berbagai keterampilan fisik, bahasa, dan anak pun mulai memiliki rasa percaya diri untuk mengeksplorasi kemandiriannya (Singgih, 2009).

Jenis kelamin anak sebagian besar laki-laki ada 27 anak (65,9\%). Jenis kelamin adalah perbedaan antara perempuan dengan laki-laki secara biologis sejak seseorang lahir (Zainal, 2011). jenis kelamin anak laki-laki atau perempuan sudah ditentukan pada saat konsepsi dan sesudahnya tidak ada yang dapat mengubah jenis kelamin anak. Anak laki-laki dalam mempersepsikan tentang suatu objek akan berbeda dengan perempuan. Perbedaan jenis kelamin cenderung membentuk persepsi yang berbeda sehingga mempengaruhi sikap yang berbeda pula antara laki-laki dengan perempuan. (Soetjiningsih, 2013)

Jumlah saudara yang dimiliki anak usia prasekolah di TK Margomulyo Sleman Yogyakarta sebagian besar yaitu tiga bersaudara sebanyak 21 anak (51,2\%). Singarimbun 
(1974) dalam Listyaningsih dan Sumini (2010) melakukan penelitian pada penduduk di sekitar Yogyakarta menunjukkan bahwa jumlah anak yang dianggap ideal 4 dan 5 orang anak. Motivasi untuk memiliki anak dalam jumlah sedikit sangat kurang, sehingga banyak terjadi jumlah anak yang diinginkan lebih besar daripada jumlah anak yang mampu dirawat dengan baik. Jumlah anak yang banyak dalam suatu keluarga juga dapat menyebabkan kurangnya perhatian dan kasih sayang yang diterima anak (Hartini, 2010). Pada keluarga yang ekonominya kurang dengan jumlah anak yang banyak dapat mempengaruhi perkembangan anak, karena selain tidak dapat memenuhi asupan gizi anak, kasih sayang dan perhatian orang tua juga akan berkurang (Soetjiningsih, 2013).

Perkembangan motorik halus yang dimiliki anak usia prasekolah di TK Margomulyo Sleman Yogyakarta sebagian besar adalah normal sebanyak 33 anak $(80,5 \%)$ dan anak yang menunjukkan perkembangan motorik halus suspect sebanyak 8 anak $(19,5 \%)$ dimana anak sulit menirukan gambar yang dicontohkan dan tidak mampu membangun menara tinggi dengan 8 kubus. Usia prasekolah (3-6 tahun) adalah usia yang sangat menentukkan dalam pembentukan karakter baik sikap, perilaku, dan kepribadian seorang anak di masa depan. Perkembangan motorik halus yang normal dapat disebabkan karena adanya rangsangan dari luar yang menumbuhkan kemampuan perkembangan motorik halus anak. Menurut Hartini (2010) rangsangan atau stimulasi adalah salah satu faktor eksternal yang sangat penting dalam menentukan kecerdasan anak. Anak yang mendapatkan rangsangan terarah dan teratur akan lebih cepat berkembang dibandingka dengan anak yang kurang atau tidak mendapat rangsangan. Selain stimulasi, ada faktor eksternal lain yang ikut mempengaruhi kecerdasan seorang anak yaitu asupan gizi dan pendidikan orang tua yang menentukan cara orang tua dalam mendidik anak dengan baik (Sudarti dan Khoirunisa, 2010). Menurut Sudarti (2010) perkembangan motorik halus anak mengacu kepada kesempatan anak untuk belajar dan berlatih, contohnya kemampuan anak dalam mencoret-coret, memindahkan benda dari tangan, menyusun balok, menggunting dan menulis (Irwin dkk, 2008). Pada penelitian ini didapatkan anak dengan perkembangan motorik halus suspect. Perkembangan motorik halus suspect ini dapat dipengaruhi oleh beberapa faktor salah satunya jumlah anak dalam keluarga yang sebagian besar memiliki 3 saudara sebanyak 21 orang $(51,2 \%)$. Jumlah anak yang banyak pada keluarga yang keadaan sosial ekonominya cukup akan mengakibatkan berkurangnya perhatian dan kasih sayang yang diterima anak (Soetjiningsih, 2013). Kondisi ini juga bisa disebabkan karena adanya masa kritis anak yang tidak disadari orang tua sehingga kurang mengantisipasi kondisi tersebut. Irwin, Siddiqi, dan Hertzman (2008) menjelaskan bahwa dalam 
perkembangan anak terdapat masa kritis, dimana diperlukan rangsangan atau stimulasi yang berguna agar potensi berkembang, sehingga perlu mendapatkan perhatian (Kusumaningtyas, dan Wayanti, 2016).

\section{Hubungan Tingkat Pendidikan dengan Perkembangan Motorik Halus}

Hasil tabulasi silang menunjukkan sebagian besar tingkat pendidikan tarakhir SMA dengan perkembangan motorik halus normal sebanyak 20 anak (48,8\%) dan 3 anak (7,3\%) dengan perkembangan motorik halus suspect. Hasil uji Spearman's didapatkan nilai signifikansi $p$-vlue $0,023<0,05$ sehingga dapat disimpulkan bahwa ada hubungan antara pendidikan ibu dengan perkembangan motorik halus anak usia prasekolah di TK Margomulyo Sleman Yogyakarta. Hasil penelitian ini sesuai dengan Apriastuti (2013) yang menyimpulkan ada hubungan yang signifikan antara pendidikan ibu dengan perkembangan motorik halus anak usia 48-60 bulan dengan nilai $p$-vlue 0,030. Demikian juga dengan penelitian Kusumaningtyas dan Wayanti (2016) yang juga menyatakan terdapat hubungan yang bermakna antara pendidikan ibu dengan perkembangan motorik halus dengan nilai $p$-vlue 0,019 , diantaranya $70 \%$ pendidikan ibu sekolah menengah atas dengan $65 \%$ perkembangan motorik halus anak normal (Iskandar, 2010).

Stimulasi adalah salah satu faktor eksternal yang sangat penting dalam menentukan kecerdasan anak. Anak yang mendapatkan rangsangan terarah dan teratur akan lebih cepat berkembang dibandingkan dengan anak yang kurang atau tidak mendapat rangsangan. Selain stimulasi, ada faktor eksternal lain yang ikut mempengaruhi kecerdasan seorang anak yaitu asupan gizi dan pendidikan orang tua yang menentukan cara orang tua dalam mendidik anak dengan baik (Hartini, 2010).

Pendidikan merupakan upaya manusia untuk mendapatkan pengalaman yang berupa pengetahuan. Semakin tinggi jenjang pendidikan yang ditempuh maka bertambah pula kedewasaan dan kemampuan seseorang tersebut dalam menyerap, mencerna, dan memahami informasi yang didapatkan. ${ }^{10}$ Tingkat pendidikan berpengaruh terhadap kemampuan orang tua (ibu) dalam menerapkan informasi yang diterimanya tentang perkembangan anak. Tingkat pendidikan yang semakin tinggi membuat ibu semakin baik dalam pembentukan karakter anak sehingga perkembangan karakter anak akan berjalan dengan baik. Sebaliknya apabila pendidikan ibu rendah, ibu akan kurang dalam membentuk karakter anak yang akibatnya pembentukan karakter anak menjadi kurang baik (Kusumaningtyas, dan Wayanti, 2016).

Pendidikan orang tua (ibu) sangat penting terhadap perkembangan anak, karena salah satu peran seorang ibu adalah sebagai pendidik di dalam keluarga sehingga pendidikan akan 
sangat penting bagi seorang ibu. Peran pendidikan ibu akan meningkatkan kemampuan anak dalam berbagai hal salah satunya kemampuan dalam perkembangan motorik halus dan berinteraksi dengan baik (Hartini, 2010). Pendidikan merupakan salah satu faktor pemudah dalam upaya peningkatan orang tua terhadap kemampuan perkembangan motorik halus anak, dimana pendidikan yang diperolah akan mempengaruhi pengetahuan dan sikap orang tua, sehingga orang tua akan lebih mudah menerima suatu ide baru. Hal ini berarti bahwa tingkat pendidikan orang tua yang tinggi akan meningkatkan kemampuan anak dalam perkembangan motorik halus yang akan dialami. ${ }^{2}$

Pada tabel 3 menunjukkan bahwa ada anak yang mendapatkan perkembangan motorik halus suspect dengan pendidikan terakhir ibu sekolah dasar sebanyak 5 anak (12,2\%). Kemampuan perkembangan motorik halus anak suspect dapat dipengaruhi oleh lingkungan keluarga yang kurang mendukung perkembangan motorik halus anak seperti kurang kasih sayang dan perhatian yang diberikan orang tua. Faktor keluarga mempengaruhi tumbuh kembang anak salah satunya jumlah saudara karena jumlah anak yang banyak dalam satu keluarga dapat menyebabkan kurangnya perhatian dan kasih sayang yang diterima anak (Soejiningsih (2013). Pada penelitian ini sebagian besar anak memiliki jumlah saudara tiga sebanyak 21 anak $(51,2 \%)$. Jumlah anak yang banyak dengan keadaan ekonomi yang kurang dapat mempengaruhi tumbuh kembang anak, karena selain tidak dapat memenuhi asupan gizi pada anak, kasih sayang dan perhatian orang tua juga akan berkurang.

Keeratan hubungan antara tingkat pendidikan ibu dengan perkembangan motorik halus anak usia prasekolah di TK Margomulyo Sleman Yogyakarta dalam kategori rendah $(\mathrm{r}=0,354)$. Keeratan hubungan yang rendah disebabkan masih banyak faktor lain yang turut mempengaruhi perkembangan motorik halus anak seperti faktor gentik dan faktor lingkungan (seperti faktor biologis, faktor lingkungan fisik, dan faktor psikososial). Pernyataan di atas sesuai dengan Soetjiningsih (2013) bahwa terdapat beberapa faktor yang mempengaruhi perkembangan motorik halus anak tidak hanya dipengaruhi oleh faktor keluarga seperti pendidikan orang tua tetapi masih ada beberapa faktor lain yang dapat mempengaruhi.

\section{KESIMPULAN}

Sebagian besar pendidikan terakhir yang ditempuh ibu dengan anak usia prasekolah di TK Margomulyo Sleman Yogyakarta adalah Sekolah Menengah Atas (SMA). Perkembangan motorik halus anak usia prasekolah di TK Margomulyo Sleman Yogyakarta sebagian besar yaitu normal. Ada hubungan antara pendidikan ibu dengan perkembangan motorik halus anak 
usia prasekolah di TK Margomulyo Sleman Yogyakarta dengan keeratan hubungan yang rendah.

Tabel 1. Distribusi Frekuensi Karakteristik Ibu

\begin{tabular}{lcc}
\hline \multicolumn{1}{c}{ Karakteristik } & Frekuensi & $\begin{array}{c}\text { Presentase } \\
(\%)\end{array}$ \\
\hline Umur & 31 & 75,6 \\
26-36 tahun & 10 & 24,4 \\
37-47 tahun & & \\
\hline Pekerjaan & 33 & 80,5 \\
IRT & 5 & 12,2 \\
Swasta & 3 & 7,3 \\
Wiraswasta & & \\
\hline Pendidikan & 0 & 0 \\
Tidak sekolah & 7 & 17,1 \\
SD & 10 & 24,4 \\
SMP & 23 & 56,1 \\
SMA & 1 & 2,4 \\
PT $\quad$ Total & $\mathbf{4 1}$ & $\mathbf{1 0 0}$ \\
\hline \multicolumn{2}{c}{} \\
\hline
\end{tabular}

Tabel 2. Distribusi Frekuensi Karakteristik Anak Usia Prasekolah

\begin{tabular}{lcc}
\hline \multicolumn{1}{c}{ Karakteristik } & Frekuensi & Presentase (\%) \\
\hline Umur & & \\
3 tahun & 0 & 0 \\
4 tahun & 2 & 4,9 \\
5 tahun & 14 & 34,1 \\
6 tahun & 25 & 61 \\
\hline Jenis Kelamin & & \\
Perempuan & 14 & 34,1 \\
Laki-laki & 27 & 65,9 \\
\hline Jumlah Saudara & & \\
Satu & 9 & 22 \\
Dua & 11 & 26,8 \\
Tiga & 21 & 51,2 \\
\hline Perkembangan & & \\
Suspect & 8 & 19,5 \\
Normal & 33 & 80,5 \\
Untestable & 0 & 0 \\
\hline \multicolumn{1}{c}{ Total } & $\mathbf{4 1}$ & $\mathbf{1 0 0}$ \\
\hline
\end{tabular}

Tabel 3. Tabulasi Silang Hubungan Antara Pendidikan Ibu Dengan Perkembangan Motorik Halus Anak Usia Prasekolah di TK Margomulyo Sleman Yogyakarta.

\begin{tabular}{|c|c|c|c|c|c|c|c|c|c|c|c|c|}
\hline \multirow{3}{*}{$\begin{array}{c}\text { Perkembangan } \\
\text { motorik halus }\end{array}$} & \multicolumn{12}{|c|}{ Pendidikan } \\
\hline & \multicolumn{2}{|c|}{ SD } & \multicolumn{2}{|c|}{ SMP } & \multicolumn{2}{|c|}{ SMA } & \multicolumn{2}{|c|}{ PT } & \multicolumn{2}{|c|}{ Total } & \multicolumn{2}{|c|}{ Spearman's } \\
\hline & $F$ & $\%$ & $\mathrm{~F}$ & $\%$ & $\mathrm{~F}$ & $\%$ & $\mathrm{~F}$ & $\%$ & $\mathrm{~F}$ & $\%$ & $\begin{array}{c}p- \\
\text { valu }\end{array}$ & rho \\
\hline Suspect & 5 & 12,2 & 0 & 0 & 3 & 7,3 & 0 & 0 & 8 & 19,5 & $\begin{array}{c}e \\
0,02 \\
3\end{array}$ & $\begin{array}{l}0,35 \\
4\end{array}$ \\
\hline Normal & 2 & 4,9 & 10 & 24,4 & 20 & 48,8 & 1 & 2,4 & 33 & 80,5 & & \\
\hline Total & 7 & 17,1 & 10 & 24,4 & 23 & 56,1 & 1 & 2,4 & 41 & 100 & & \\
\hline
\end{tabular}

\section{DAFTAR PUSTAKA}

Cahyaningsih, D. S., 2011. Pertumbuhan perkembangan anak dan remaja.Jakarta: TMI.

Dinas Kesehatan DIY., 2011. Profil kesehatan kabupaten gunung kidul. Yogyakarta: Dinkes.

Dinas Kesehatan Sleman., 2012. Profil kesehatan kabupaten sleman. Yogyakarta: Dinas Kesehatan Sleman.

Hartini., 2010. Hubungan stimulasi dan karakteristik ibu dengan perkembangan personal sosial anak usia 3-5 tahun di PAUD anak ceria Pedurungan Lor Semarang (Skripsi). Program Studi Ilmu Keperawatan. Fakultas Ilmu Keperawatan dan Kesehatan. Universitas Muhammadiyah Semarang.

Hurlock, E., 2011. Psikologi perkembangan. Jakarta: Erlangga. 
Ikatan Dokter Anak Indonesia., 2013. Mengenal keterlambatan perkembangan umum pada anak. Jakarta. Diakses pada: http://www.idai.or.id/ [Diakses 11 Oktober 2017].

Irwin, Lori G., Arjumand Siddiqi, \& Clye Hertzman., 2008. Early child development: a powerful equalizer final report. Canada: Public Healty Agency.

Iskandar., 2010. Psikologi pendidikan. Ciputat: Gaung persada press.

Kementerian Kesehatan RI, 2012. Pedoman stimulasi, deteksi, dan intervensi dini tumbuh kembang anak ditingkat pelayanan kesehatan dasar. Jakarta: Kementerian Kesehatan Republik Indonesia.

Kementrian Kesehatan RI., 2013. Profil kesehatan Indonesia. Jakarta : Depkes RI. Diakses pada: http://www.depkes.go.id/index.php [Diakses tanggal 11 Oktober 2017].

Kusumaningtyas, K., dan Wayanti, S., 2016. Faktor pendapatan dan pendidikan keluargaterhadap perkembangan motorik halus anak usia 3-4 tahun. Jurnal Penelitian Kesehatan Suara Forikes, VII(1), h.52-58.

Notoatmodjo, S. 2010. Metodologi penelitian kesehatan. Jakarta: Rineka Cipta.

Potter, P. A., and Perry, A. G., 2012. Buku ajar fundamental keperawatan konsep, proses dan praktek. Edisi 4. Jakarta: EGC.

Santrock. J.W., 2011. Masa perkembangan anak, Edisi 11 Jilid 2. Jakarta: Salemba Humanika

Singgih. G., 2009. Psikologi anak: psikologi perkembangan anak dan remaja. Jakarta: Gunung Mulia.

Soekanto, S., 2010. Sosiologi suatu pengantar. Jakarta: Rajawali Pers.

Soetjiningsih., 2013. Tumbuh kembang anak. 2rd ed . Jakarta: EGC.

Sudarti, E. Khoirunisa., 2010. Asuhan kebidanan neonatus, bayi, dan anak $\quad$ balita. Yogyakarta: Nuha Medika.

Supartini, Y., 2010. Buku ajar konsep dasar keperawatan anak. Jakarta: EGC.

Syah, M., 2010. Psikologi pendidikan dengan pendekatan baru. Bandung: PT Remaja Rosdakarya.

Widyastuti, Y., Rahmawati, A., dan Purnamaningrum, Y. E., 2010. Kesehatan reproduksi. Yogyakarta: Fitramaya.

Wong, D.L., Eaton, M. H., Winkelstein, M. L., and Schwartz, P., 2009. Buku ajar keperawatan pediatrik. Jakarta: Buku Kedokteran EGC

UNICEF., 2010. Angka kejadian pertumbuhan dan perkembangan anak balita. Diakses pada http://www.unicef.org/ [Diakses tanggal 11 Oktober 2017].

Zainal, A., 2011. Penelitian pendidikan. Bandung: Remaja Rosdakarya. 